\title{
DEVELOPMENT FINANCING AND ECONOMIC GOVERNANCE: ANALYSIS OF THE LIQUIDITY CRISIS AND CIRCULARITY DEBTS IN PAKISTAN
}

\author{
Dr. Muhammad Irfan Khan ${ }^{1}$ \\ Iqra University Main Campus, Karachi \\ Dr. Muhammad Ayub Khan Mehar ${ }^{2}$ \\ Iqra University Main Campus, Karachi \\ Dr. Athar Iqbal ${ }^{3}$ \\ Iqra University Main Campus, Karachi
}

\begin{abstract}
Purpose: This paper is based on the models derived by the researchers to explain the patterns of corporate governance, firms' financial policies and liquidity position.

Methodology: A deductive approach has been adopted to reconcile and examine the different models of corporate governance and firms' financial policies.

Findings: The study showed that corporate savings is a good predictor of the macro level investment in a country. The magnitude of national investment will increase by improvement in corporate savings. In fact the corporate savings indicate the expansion in business activities which may be an indicator of the trust and confidence of private sector. On the other hand it explains the financial health of corporate sector, which may provide the significant portion of tax revenue to the government for developing projects in public sector. The study has concluded that corporate governance is a significant variable in determining the liquidity and circularity debts. In this way corporate governance becomes a crucial determinant of the national investment.

Implications:The bad corporate governance may deteriorate the investment activities at national level, which may damage the economy for a longer term. This study also indicates that capital structure and the patterns of ownership play important role in the determination of corporate governance of an institution.
\end{abstract}

Key Words: E60 M48, 010.

* The material presented by the author does not necessarily portray the viewpoint of the editors and the management of the Institute of Business \& Technology (IBT)

1. Dr. Muhammad Irfan Khan

2. Dr.Muhammad Ayub Khan Mehar

3. Dr. Athar Iqbal

$$
\begin{aligned}
& \text { : mirfan@iqra.edu.pk } \\
& \text { : ayubmehar@yahoo.com } \\
& \text { : athar@iqra.edu.pk }
\end{aligned}
$$

C IBT-JBS is published by the Institute of Business and Technology (IBT). Main Ibrahim Hydri Road, Korangi Creek, Karachi-75190, Pakistan. 


\section{INTRODUCTION}

Economic governance is a theoretical concept that covers issues in many pastures. It includes economic development and growth, organizational behavior, political economy and the like. Williamson (2005) explains the economic governance as the "study of good order and workable arrangements". It studies processes which support economic transactions and different activities. These processes are followed within formal and informal institutions. The formal and informal institutions in a country progress to undertake different economic activities. Problem arises when informal activities are found within the formal system of organizations. These informalities may be found in any formal system i.e. political system, financial system, economic system and the like. At times, organizations may be involved in these informal economic activities. They may take undue benefits of concentrated ownership, poor protection of shareholders in minority and accepting projects which may destroy the wealth of shareholders. These activities are termed as a problem of corporate governance. Economic governance studies the institutions and organizations while corporate governance deals with internal management of a corporation (Dixit, 2008).

Vitols (1995) compared the New Institutional Economies (NEIs) perspective and economic governance perspective. The study found that later perspective focuses on macro level. This paper takes up economic governance perspective to support the argument that it can lead to higher amount of macro level investment in a country. For this purpose, corporate governance is taken as one of the offshoots of the economic governance.

In the neoclassical approach, high rate of investment is directly linked with high rate of savings. In the non-neoclassical approach, savings are not automatically translated into investment but have a causal relationship. According to this approach, profits are the outcome of investments. This paper takes the non- neoclassical approach where savings and investment are not directly linked but there are some reasons behind them.

The aim of this paper has many folds. First, it attempts to investigate the corporate governance practices being followed in the public listed firms in Pakistan. Some big families in Pakistan have more than one business. Transfer of one CEO to another company is a common practice which hinders the corporate governance practices. Similarly, compensation of CEOs is also biased due to relationship based corporate governance structure. Salaries and other requisites are not performance based, rather determined either on political or relation grounds. Managerial remuneration to capital is taken as the proxy of corporate governance.

Secondly, the study aims to examine the issue of liquidity problem exists in the form of circularity debt mainly in the energy sector of Pakistan in relation to corporate governance. It is an attempt to explain not only the factors contributing good corporate governance but also to seek an understanding of its relationship with circularity debt with respect to liquidity crisis. The study has a fundamental premise that bad corporate governance is responsible for circularity debt and liquidity crisis. Pakistan has been facing this phenomenon for almost one decade. There were several solutions given but no one was long run. This study is an endeavor to recommend a long lasting as well as beneficial solution for both the government as well as all stakeholders. Circularity debt shows illiquidity of firms which results when one party holds the payment of other party in the supply chain. This not only hurts the operation of the company but country also faces losses in terms of GDP. It is hypothesized that circularity debt issue arose because of bad corporate governance practices being implemented in Pakistan along with some other explanatory variables.

It also intends to explore the causes based on which firms decide to retain their earnings and increase the equity. The decision of retained earnings epitomizes the financing policy of the company. Firms having good future investment opportunities retain a large portion of earnings after tax. According to pecking order theory, firms always put retained earnings as 
first priority whenever fund is needed. This phenomenon is examined with liquidity and earnings of the company as explanatory variables.

Finally, the paper recommends a path way to a developing country to progress by increasing the corporate savings. It is revealed that investment in the country depends on corporate savings.

These objectives are interlinked with each other with separate propositions. Dependent variable in the first proposition becomes explanatory variable in the second proposition. Similarly, dependent variable in the second proposition takes the position of independent variable in the third proposition and so on till the forth proposition. Based on a combination of endogenous as well as exogenous variables, the paper finally argues that corporate savings are a good indicator to macro level investment of the country.

\section{CIRCULARITY DEBT}

The study intends to elucidate that good corporate governance can diminish the issue of circularity debt exist in Pakistan. Circularity debt arises when one entity faces problems in its cash inflows and consequently fails to discharge its obligations. Similarly, second entity does not receive its payments; it further withholds the disbursement to other entity. As a result, this perturbs all segments of the payment chain. This warm and unresolved issue persists mainly in the power sector of Pakistan as well as some other government owned firms like Pakistan International Airline, Pakistan Steel Mills and Pakistan Railways. The amount of reported circularity debt is the sum of the receivables of each organization. Payable of one organization becomes receivable for another organization. When subtract one from the other, these should be canceled out or the difference should be smaller in number. In case of power sector in Pakistan, this amount was estimated to be Rs.537 billion as on June 30, 2011 and Rs.872 billion as on June 30, 2012, account for roughly 4\% of the nation GDP (Planning Commission of Pakistan, 2013). To comprehend these issues, it is imperative to look at the key organizations which involve in the supply chain.

\subsection{Supply Chain of the Circularity Debt in the Energy Sector of Pakistan \\ 2.1.1 The suppliers of primary energy}

This segment of the chain provides energy to power generation companies. The chain begins from the exploration of oil and gas. These include companies like OGDCL and PPL. These companies transfer oil/gas to oil refineries companies which are ARL and PARCO. Accordingly, oil refineries supply to distribution companies. They supply gas distribution companies like SNGPL and SSGC and oil distributing companies like PSO and Shell.

\subsubsection{The Power Generation Companies}

The second step in the chain starts when exploration companies supply energy to this segment. The companies which are involved in power generations are KESC, IPPs, CPPA, WAPDA and PEPCO. The core entity in the energy sector is PEPCO which is an umbrella institution engaged in managing power generation companies (GENCOs), the National Transmission and Dispatch Companies (NTDC) and power distribution companies (DISCOs).

\subsubsection{The Power Distribution Companies}

This segment obtains energy from the generation companies and distribute to individuals, industrial consumers, Government, FATA, etc. These comprise companies like LESCO, 
HESCO, IESCO, MEPCO, FESCO, PESCO, QESCO and GEPCO and are collectively called DISCOs.

PEPCO is an umbrella company which is responsible to collect tariffs from its customers and Government as well and disburse to its suppliers like IPPs, OMC and gas companies. Cash inflows and outflows must be logically comparable in order to function the business smoothly. Cash outflows of the PEPCO are sure because these are obligation which has to be fulfilled. Cash inflows are uncertain because of absence or delay in tariffs payments. Sometimes government delays in subsidies while on the other hand, some powerful individual and government institutions withhold their payment. Ultimately this accumulates the receivable amount in the PEPCO account which results delay in payment to its suppliers which in turn seize payment to top of the segment. This imbalance of cash flows is one of the reasons of circularity debt. Table 1 shows the receivables from all distribution companies, called DISCOs from 2008-09 to 2011-12 along with their share in the total receivables.

This is evidenced in the table 1 that poor revenue collection by PEPCO from DISCOs is one of the causes of circularity debt. This problem is not identical in the country as some of the DISCOs have good track record. One of the reasons which contribute to the hike in receivables is the lack of accountability of DISCOs. High political interference, low transparency and failure of accountability do play a significant role, showing corporate governance issue which must be addressed.

It is reality that there are a bulk amount of receivables in the books of PEPCO from DISCOs but on the other hand, DISCOs also have a huge amount of receivable from different provinces of Pakistan. Table 2 gives the fact of these receivables. In fact, receivables gradually increased from 2005 to 2012 . Baluchistan is the top of the list which has to pay highest amount in the year of 2012.

The study implies that good corporate governance can improve the management of liquid assets (working capital). Table 3 shows some highlights of the receivables and payables of public corporation in Pakistan for 2010 and 2011. It can easily be comprehended that receivables are greater than payables which implies that circularity debt is the governance issue which can be overcome through good governance.

Circularity Debt is taken as a proxy of liquidity. It takes the value of 1 if the firm faces the problem of circularity debt and zero otherwise.

It is hypothesized that circularity debt arises because of poor corporate governance. Zheka (2007) suggested positive relationship between improved liquidity position and good corporate governance practices. García-Teruel, Pedro and Juan (2009) found inverse relation between accounting accruals quality and the cash level by firms.

\section{CORPORATE SAVING DECISIONS}

One of the components of national savings is the corporate savings which account for a large portion of it. China's corporate savings as of GDP in 2003 was $18 \%$ or US $\$ 700$ billion (China's National Bureau of Statistics). China is not the only country with higher corporate savings but other countries like India, Australia and the UK are also on the same line. J.P.Morgan (2005) and IMF (2005) observed that companies in G-7 economies have presented an increase in undistributed profit. Literature of corporate finance does not believe high corporate savings as inefficiency or corporate mis-governance. It could be a result of increasing working capital needs faced by corporations. Fama \& French, (2001) studied a pattern of not paying dividend in the U.S. from 1978 to 1999. 
The ultimate objective of a corporation is to maximize shareholder's wealth. The share price carries future information about companies' affairs and business decisions. If share price rises in spite of the low dividend announcement, it is evidenced that the firm has good investment opportunities not only from company's perspective but also in the eyes of investors. Ultimately, shareholders will get benefit from this retained earnings in the future. Modigliani $\&$ Miller (1958) suggest that only the required return is relevant from investors' point of view. If it is fulfilled, dividend becomes irrelevant.

The issue of retained earnings may be viewed either from the macroeconomic perspective or in connection with corporate finance. Economic standpoint of the subject is interested to examine the cyclical fluctuation of the economy. While corporate finance studies the matter with a view to the rights and interests of owners and managers of a corporation.

This paper has a strong proposition that corporate savings are a good indicator of macro level investment in a country. By having this proposition, it intends to merge the economic theory with the corporate finance. The effect of retained earnings on the total investment in the country depends upon the investment in different type of assets by the company, decisions of capital structure, liquidity position of the firm, positive cash flow from operations, profitability and corporate governance practices within the firm. Good corporate governance lead the firm to better liquidity management, which in turn, let the firm to retain some earnings and invest in the profitable and positive NPV projects. This will increase the total investment in the country.

There are favorable as well as unfavorable arguments of the corporate savings. Advocates of retained earnings assert that it facilitates corporations to accumulate the cash surplus during the business growth which, in turn, strengthen the firm to resist the adverse effect during the time of business failures. While challengers of the subject argue that cyclical fluctuations is intensified by this decisions. Furthermore, they also reiterate that reinvestment of corporate earnings is easy to misallocate of resources. Having for and against arguments, the decisions of retained earnings have the following key benefits which are hard to ignore.

1. Accumulation of cash in good times and uses them in bad times.

2. In contrast to external equity, the retained corporate profit reduces the issue cost and losses because of under-pricing (Chandra, 2002).

3. Retention of earnings is likely to increase new investment in the economy (Dobrovolsky, 1945).

4. Reinvestment of corporate savings does not have same pressure from stockholders to earn the required return as compare to funds obtain from the capital market. (Dobrovolsky, 1945).

5. There are no transactions as well as bankruptcy costs involved with retained earnings (Altman, 1993).

Weidenhammer (1933) discussed the eminent role of corporate savings in the capital formation in the England and Germany. He argued that investment through retained earnings adds high sub-marginal returns than the funds generated through capital market. It was suggested that increased percentage of retained earnings with respect to capital formation lead to high fluctuations in interest rate in the capital market. The study mainly focused on the faulty investment of retained earnings and pointed out separation of ownership \& control and management as two major factors behind it.

Myers \& Majluf (1984) also talked of the importance of retained earnings of companies in connection with not only at macro but also at the micro level. They pointed out that corporate savings are the best source of financing in terms of risk and costs. 
Shanta (1982) investigated the importance of corporate sector in the domestic savings in India. The study found a decline trend in the corporate savings during 1975-76 to 1978-79, indicating a small share in the overall economy of the India. Bhole \& Jitendra (2005) studied the determinants of retained earnings in India while taking the data from 1966 through 2000. They advocated that high rate of economic growth with stability may be achieved if corporate savings rate become high as well. Significant determinants of retained earnings in this study were profit after tax, availability of external funds, investment opportunities, cost of borrowing and cost of equity.

The debate of allocating corporate profit between dividend and retained earnings dates back to the study of Lintner (1956) which argues to drive behavioral relationships of dividend and to treat retained earnings as residual. Turnovsky (1967) provided a counter argument against the present studies that retained earnings may be a residual but are still governed by some behavioral relationship. He estimated dividend equation as well as gross retained earnings equations and found that firms strive to find their dividend more urgent but the result is not statistically significant. Secondly, last year gross profit in the retained earnings equation is significantly negative while positive in the current year level, indicating that it changes the profits and current level which ultimately determines as how much should be retained by the corporations. Thirdly, retained earnings are determined by the transitory components of profits. Furthermore, the study also revealed that retained earnings are determined by the current profit which is opposite of dividend decisions. As far as the decision of investment is concerned, no statistically significant result was found, implying that investments play a minor role in determining the retained earnings.

The decision of retained earnings reflects the capital structure policy of firms. This internal financing ratio during 1970-1985, was $100 \%$ in the non-financial firms of the UK. In the US, this ratio was $85 \%$ while around $60 \%$ in Japan. Firm in Pakistan showed $58.3 \%$ in the same period (D'Souza, 2000). Firms with high amount of circularity debt tend to hold high percentage of earnings to efficiently run the business operations. Table 4 illustrates the percentages of internal financing ratio of top 50 manufacturing companies in different countries.

\section{INVESTMENT IN PAKISTAN}

The flows of foreign direct investment as well as domestic investments in GDP remain slow during 1990s and 2000s. Even the share of domestic investment in GDP was continuously declining. Most of the time it is argued that investment in a country also depends on FDI and other remittances. Table 4 shows some facts of the history of investment in Pakistan as percentage of GDP either in the form of foreign direct investment (FDI) or domestic investment (GFCF).

Examination of the table 5 reveals that there is no relationship between the two economic variables. If one increases another decreases. Reading the table from top to down, we come to know that FDI as percentage of GDP increased from 0.61 to 1.03 from the year 1990-91 to 2007-08. GFCF as percentage of GDP, in the same number of years, decreased from 17.30 to 15.55. Besides, each variables show opposite directions every time during the time span of 1990-91 to 2007-08. For instance, in the year 1990-91 the FDI as of GDP was 0.61 while GFCF as of GDP was 17.30. In the next year 1991-92, FDI decreased to 0.57 but the GFCF increased to 17.47. Similarly, in the 1994-95 FDI as of GDP was 0.81 and GFCF as of GDP was 17.97. In the next year 1995-96, the FDI as of GDP increased to 1.19 while GFCF as of GDP declined to 17.03. Mean values are far from each other, showing for FDI 0.9533 while 
for GFCF is 16.3783. Moreover, there is negative insignificant statistical correlation between the two, showing -0.261 insignificant correlation.

1990s was the starting ear where government of Pakistan, with some exceptions, allowed the same rules to foreign investors as being applied to domestic investors. In the 2000s, investment policy was based on the principles of privatization, liberal remittances and the like by the government of Pakistan.

Figure 1 also strong our understanding about no relationship between FDI and GFCF as percentage of GDP. The magnitude of both of the variables is far from each other. In most of the time, both variables went on opposite directions.

It gives little evidence that investment in Pakistan is not dependent only upon the FDI but other sources are also having importance. Out of these other important sources, corporate savings are the main source of investment in Pakistan or elsewhere.

\section{GROSS FIXED CAPITAL FORMATION (GFCF)}

Formerly known as gross domestic investment, covers the investment in fixed assets of the economy as well as net changes in the inventory level. Fixed assets comprise plant, machinery, land improvement, equipment, and construction of road, railways, schools, hospitals, and private as well as commercial buildings. Inventories include stocks of goods taken by firms to meet day to day fluctuations in sales, production or work in progress.

Empirically, society, as a whole, does not take quick benefit out of it but contribute in making goods as discussed above to largely increase the efficacy of productive endeavor. It is confirmed, through the economic theory and experience that the differences in the economic development as well as growth are intertwined with the differences in the composition level of capital stock. This capital stock is buildup by the capital formation accumulation.

Thus, economists have been using the estimation of capital formation and capital stock to analyze the results of productive activity. As compared to developed countries, developing countries like Pakistan have shortage of capital and natural resources. Therefore, the central problem in these countries is the accumulation of capital formation. The thesis is aimed at confirming the dependency of GFCF on corporate savings.

All of these stated investments in the country are made either by state-owned or privateowned firms. An increase in retained earnings by firms can boost the capital investment in the country. Figure 2 depicts the history of GFCF in Pakistan over the period of 1960 to 2011. Increase in the investment in GFCF started somewhere in 1982 and reached at its peak in the year 2011. Consistent increase shows the interest of government in this respect as shown in table 4, almost $58 \%$ of the investment in Pakistan came from internal financing.

\section{PROPOSITIONS}

\subsection{Proposition 1}

- $\quad$ Firm specific factors explain corporate governance practices.

Firm specific factors include type of the organization (ORGTYP), ownership concentration (OWNCONCT), log of capital (LOGCAP) and distribution of Assets (CAFA).

$$
C G=\alpha_{0}+\alpha_{1} O R G T Y P+\alpha_{2} O W N C O N C T+\alpha_{3} L O G C A P+\alpha_{4} C A F A
$$

Where $\alpha$ is the parameter

This proposition leads to the following corollaries. 


\subsubsection{Corollary 1}

Public sector ownership of a firm affects the pattern of institutional governance.

The corollary (1) explains that firm specific variables- type of organization determine the governance practices. The governance practices may differ in the fully private organization from the public sector organization.

The institutional settings of government and privately owned firms are different. Governance is weaker in government-owned corporations as compared to privately-owned firms. Salary and other perquisites of CEOs in government corporations are higher as compared to the IPPs in private sector due to political influence in public sector.

\subsubsection{Corollary 2}

Ownership concentration distorts the corporate governance practices. The higher concentration of ownership may derail the goal of value maximization of a firm. The value of a firm has a direct relation with the wealth of shareholders. The role of directors in highly concentrated firms may force the management to pay personal expenses of directors in indirect ways. The entertainment cost, travelling, special benefits and cost of living allowances may be included in these personal expenses. It is the additional agency cost paid by the highly concentrated firms. It is obvious that directors may save their personal income by shifting the personal expenditures in firms' accounts. The personal savings of the directors increase their personal wealth and this practice may create a dichotomous between the directors and shareholders' objectives.

The probability of such practices is higher in small firms as compared to the large firms. In global comparison and categorization of companies in Pakistan, the majority of companies in the energy sector is classified as small firms.

\subsubsection{Corollary 3}

The combination of debt and equity plays a pivotal role in determining the governance practices.

A high leverage firm will force the company to reduce its expenditures. The increment in salaries and fringe benefits are included in these expenditures. The firm has to pay interests on its debt liabilities and the redemption of liabilities will also affect the liquidity of the company. It is obvious that to manage the financial resources, a firm has to scarify its liberty to increase the expenditure on payments of fringe benefits to the directors of top level management. Therefore, a negative correlation may be assumed between the governance practices and leverage ratio of a firm.

\subsubsection{Corollary 4}

High amount of current assets lead to higher expenditures on top management. The higher proportionate of current assets in the total assets of a company will lead to more liberty to the directors and top level management to increase their salaries and other benefits. If large part of the capital is invested in the form of fixes assets, it will restrict the liberty to increase in the expenses on salaries and benefits. Higher magnitude of current ratio can be transformed into cash either by recovering of receivables or sale of inventories. 


\subsection{Proposition 2}

- Good corporate governance leads to better liquidity management in a firm.

Circularity debt $(\mathrm{CD})$ is the proxy of liquidity

$C D=\beta_{0}+\beta_{1} C G+\beta_{2} L O G L T D+\beta_{3}$ CFTNAST $+\beta_{4}$ CAPEXPTNAST $+\beta_{5}$ LOGSALES

By incorporating model 1 into it, we have;

$=\beta_{0}+\beta_{1}\left(\alpha_{0}+\alpha_{1}\right.$ ORGTYA $\alpha_{2}$ OWNCONCF $\alpha_{3}$ LOGCAR $\alpha_{4}$ CAFA $+\beta_{2}$ LOGLTA $\beta_{3}$ CFTNAST

\section{$\beta_{4}$ CAPEXPTNAS+ $\beta_{5}$ LOGSALES}

So we have

$=\beta_{0}+\alpha_{0} \beta_{1}+\alpha_{1} \beta_{1}$ ORGTYP $+\alpha_{2} \beta_{1}$ OWNCONCT $+\alpha_{3} \beta_{1}$ LOGCAP $+\alpha_{4} \beta_{1}$ CAFA $+\beta_{2}$ LOGLTD +

$\beta_{3}$ CFTNAST $+\beta_{4}$ CAPEXPTNAS $+\beta_{5}$ LOGSALES

While CG is the predicted values of corporate governance taken from model 1 Where $\alpha$ and $\beta$ are the parameters

Followings are the corollaries of the proposition 2

\subsubsection{Corollary 1}

Circularity debt problem can be mitigated by good corporate governance practices. It will lead them to take decisions, for instance leverage, which is aligning with all the shareholders of the firm.

\subsubsection{Corollary 2}

Decisions of board of directors like investment in fixed assets, management of cash flow and growth in sales are very much related to liquidity management.

\subsection{Proposition 3}

- Better liquidity management leads to retention decisions (LOGRE) by the managers.

$$
L O G R E=\gamma_{0}+\gamma_{1} C D+\gamma_{2} R O E
$$

$\mathrm{CD}$ is the predicted values of circularity debt taken from model 2. By incorporating model 2 into it, we have;

$=\gamma_{0}+\gamma_{1}\left(C_{0}+\alpha_{1} \beta_{1}\right.$ ORGTYP $+\alpha_{2} \beta_{1} O W N C O N C T+\alpha_{3} \beta_{1} L O G C A P+\alpha_{4} \beta_{1} C A F A+$

$$
\left.\beta_{2} L O G L T D+\beta_{3} C F T N A S T+\beta_{4} C A P E X P T N A S T+\beta_{5} L O G S A L E S\right)+\gamma_{2} R O E
$$

So we have

$$
\begin{aligned}
& =\gamma_{0}+\gamma_{1} C_{0}+\gamma_{1} \alpha_{1} \beta_{1} \text { ORGTYP }+\gamma_{1} \alpha_{2} \beta_{1} \text { OWNCONCT }+\gamma_{1} \alpha_{3} \beta_{1} L O G C A P+\gamma_{1} \alpha_{4} \beta_{1} \text { CAFA }+ \\
& \gamma_{1} \beta_{2} L O G L T D+\gamma_{1} \beta_{3} \text { CFTNAST }+\gamma_{1} \beta_{4} \text { CAPEXPTNAST }+\gamma_{1} \beta_{5} \text { LOGSALES }+\gamma_{2} \text { ROE }
\end{aligned}
$$

$$
\text { Let } \gamma_{0}+\gamma_{1} C_{0}=\quad C_{1}
$$

Because this is constant or intercept of the model

$$
\begin{aligned}
& \text { LOGRE }=C_{1}+\gamma_{1} \beta_{1}\left(\alpha_{1} O R G T Y P+\alpha_{2} O W N C O N C T+\alpha_{3} L O G C A P+\alpha_{4} C A F A\right)+\gamma_{1}\left(\beta_{2} L O G L T D+\right. \\
& \left.\beta_{3} C F T N A S T+\beta_{4} C A P E X P T N A S T+\beta_{5} L O G S A L E S\right)+\gamma_{2} R O E
\end{aligned}
$$




$$
\begin{aligned}
& \text { LOGRE }=C_{1}+\gamma_{1}\left[\beta_{1}\left(\alpha_{1} O R G T Y P+\alpha_{2} O W N C O N C T+\alpha_{3} L O G C A P+\alpha_{4} C A F A\right)+\beta_{2} L O G L T D+\right. \\
& \beta_{3} \text { CFTNAST }+\beta_{4} \text { CAPEXPTNAד }+\beta_{5} L O G S A L E S+\gamma_{2} R O E
\end{aligned}
$$

Where $\gamma$ is the parameter

Therefore, retained earning is an exponential function to measure.

$$
\begin{aligned}
& \left(C_{1}+\gamma_{1}\left[\beta_{1}\left(\alpha_{1} \text { ORGTYP }+\alpha_{2} \text { OWNCONCT }+\alpha_{3} L O G C A P+\alpha_{4} C A F A\right)+\beta_{2} L O G L T D+\right.\right. \\
& R E=e^{\left.\left.\beta_{3} \text { CFTNAST }+\beta_{4} \text { CAPEXPTNAST }+\beta_{5} L O G S A L E S\right]+\gamma_{2} R O E\right)}
\end{aligned}
$$

Followings corollaries have been established based on above derivation.

\subsubsection{Corollary 1}

Corporate savings will be a function of good liquidity management and equity earnings.

\subsubsection{Corollary 2}

Firm specific variables will escort the corporations to make decisions which can reduce the agency conflicts.

\subsection{Proposition 4}

- A higher level of corporate savings will lead to higher investment in the country.

Total investment in the country is Gross Fixed Capital Formation (GFCF) and corporate savings is retained earnings (LOGRE) by corporations.

$$
G C F=\psi_{0}+\psi_{1} L O G R E
$$

Where $\psi$ is the parameter

And RE equals to

$$
\begin{aligned}
& \left(C_{1}+\gamma_{1}\left[\beta_{1}\left(\alpha_{1} \text { ORGTYP }+\alpha_{2} \text { OWNCONCT }+\alpha_{3} L O G C A P+\alpha_{4} C A F A\right)+\beta_{2} L O G L T D+\right.\right. \\
& R E=e^{\left.\left.\beta_{3} \text { CFTNAST }+\beta_{4} \text { CAPEXPTNAST T+ } \beta_{5} L O G S A L E S\right]+\gamma_{2} R O E\right)}
\end{aligned}
$$

That's why

$$
\begin{aligned}
& \left(C_{1}+\gamma_{1}\left[\beta_{1}\left(\alpha_{1} O R G T Y P+\alpha_{2} O W N C O N C T+\alpha_{3} L O G C A P+\alpha_{4} C A F A\right)+\beta_{2} L O G L T D+\right.\right. \\
& G F C F=\psi_{0}+\psi_{1} e^{\left.\left.\beta_{3} C F T N A S T+\beta_{4} C A P E X P T N A S T+\beta_{5} L O G S A L E S\right]+\gamma_{2} R O E\right)}
\end{aligned}
$$

\subsubsection{Corollary 1}

Development in terms of macro level investment in a country depends on retained earnings by corporate sector.

\subsubsection{Corollary 2}

Firms with good corporate governance practices will lead in the macroeconomic development in a country. 


\section{Basic Assumptions of the Model}

1. There are only two types of firms i.e. public limited and private limited.

2. Investment of retained earnings must be utilized in either merchandise inventory and/or fixed assets.

3. Good corporate governance practices in necessary to achieve the objective of firms.

4. All firms in the market are levered.

\section{Theoretical Model of the Dissertation}

As discussed above, the ultimate objective of the thesis is to systematically prove the dependency of total investment in the country on corporate savings. The responsibility of social as well as economic development has now been partially shifted from government to private sector. It is, therefore, imperative to recognize the importance of corporations in order to attract more investment in the country. The theorem starts from the premise that corporate governance, as one of the offshoots of the economic governance can be explained by firm specific as well as some exogenous variables. Any change in any of the exogenous explanatory variable will automatically change the corporate governance settings, and hence economic governance.

The second part explains the causes of circularity debt which results the liquidity problem among firms. These causes are exogenous variables along with the predicted values of corporate governance taken from the first model. It is hypothesized here that corporate governance can mitigate the problem of rising circularity debt exist in the economy.

The third part attempts to examine that retained earnings by corporations is a function of equity earnings and the predicted values of liquidity taken from the second model. It must be kept in mind here that predicted values of liquidity also include predicted values of corporate governance. Therefore, it must be interpreted within the context of corporate governance. Finally, corporate savings is assumed to be a predictor of total investment of the country. Since all part of the model is interlinked with each other, corporate savings cannot be viewed separately. It is systematically deduced through a derivation sated in propositions.

\section{Data and Variables}

This research is aimed at studying and exploring the dependency of investment in a country on the corporate savings through a theorem. This is systematically examined through a derivation of four interlinked theoretical models. In order to achieve these objectives, secondary data was collected through audited annual accounts of sampled companies. In order to separate government-owned firms from IPPs, firms with more than $60 \%$ shares are assumed to be government owned. Data of Gross Fixed Capital Formation (GFCF) as the proxy of total investment in the country was collected from various issues of the economic survey of Pakistan. Data collected from these sources was then analyzed and interpret with the support of literature. There is much literature available, explaining the phenomenon of governance. Most of them were studied in the context of developed economies. Very little efforts were made to explore the area in developing or third world countries. This research is a value addition in the literature of economic governance particularly in Pakistan as the circularity debt issue only exists in Pakistan. 


\section{Estimation Techniques}

There are four integrated theoretical models. Corporate governance which is endogenous variable in first model becomes exogenous in the second model. Similarly, liquidity which is endogenous variable in the second model becomes exogenous in the third model. Because of the nature of the models, 3-stage least square regression is appropriate to explain the phenomenon. The model is non-recursive as there are some reciprocal paths between models. In such cases, single equation estimation techniques like 2SLS may not provide an efficient estimate as 3SLS (Judge, Griffiths, Hill, Luthepohl and Lee 1985).

\section{Results and Analysis}

\subsection{Descriptive nature of the data}

Table 8 depicts the descriptive statistics for the variables used in the analysis. Analysis includes mean and standard deviation of all variables used in the theorem. It shows that ownership concentration (OWNCON) and capital (LOGCAP) have same mean score while corporate assets (CA/FA) has a mean value more than of all variables with different standard deviations. Ownership concentration is the number of shares held by directors and capital means long term debt plus equity. Since both variables do not have same unit of analysis, no proper explanation can be justified. Corporate assets (CA/FA) have a mean value of 99.4167 with the standard deviation of 12.45824 . The mean value of this variable indicates that this ratio reaches almost $100 \%$ which shows heavy investments by firms in the form of liquid assets like cash or marketable securities. The type of organization (TORG) is a dummy variable which has a value of either 0 or 1 , hence cannot be compared with rest of other variables. Examination of table 8 also reveals some interesting facts. Mean score of long term debt (LOGLTD) and sales (LOGSALES) are more or less same. This result may be interpreted that long term debt of companies in the energy sector of Pakistan is, on average, near to total sales of the sector. This situation is supportive of the problem of circularity debt. As the credit sales increase, it becomes difficult to recover from the customers. To avoid the situation of lower cash inflows, companies in the payment chain starts borrowing from banks and increase the debt. If all of the cash flows, generated through sales, are used to pay off the long term debt, companies will be unable to meet its short term obligations, resulting inefficient operations. Mean value of cash flow to noncash asset (CFTNA) is 11.425 while capital expenditure to net asset is 146.962.

Mean of retained earnings and return on equity are far from each other. Mean value of ROE (34.1135) is six times more of the mean of LOGRE (5.9146). It may be assumed that corporations have a possibility to increase the retained earnings while setting the dividend policy in line with the companies' objective. Available growth opportunities can be availed only if a firm has sufficient cash management. Retained earning is the economical option to opt any new project by a firm. Profitability can be an objective of an investor who is present in the market for a very short span of time. Rational investors always look for far future in terms of the sustainability of the firm. A firm can be sustained in the market if it also depends on its earnings rather than sources outside the firm.

\subsection{Determination of Corporate Governance}

Table 9 illustrates the regression results of proposition 1. As discussed, type of organization is introduced as a dummy variable, taking the value of 1 in case of government-owned listed 
firms and 0 for private-owned listed firms. The results in table 9 show that in the absence of private-owned listed firms, there is positive and significant relationship with the corporate governance proxy. It reveals that directors in the government-owned listed firms get benefit by increasing their salary and other perquisites while this is not in case of private-owned listed firms. This evidence is supportive of the general arguments prevailed in the market and among institutional as well as individual investors. This depicts the bad corporate governance practices being practiced in government-owned firms. This is also one of the reasons as to why this sector is not helping common people in the form of providing proper electricity in the country.

Ownership concentration has a negative impact on corporate governance practices of firms. Corporations with concentrated ownership allow directors to get maximum benefit from the firm. Their salary and other perquisites are increased for nothing. If some controlling shareholders are dominant in the firm, they will enjoy this opportunity to be benefited from this option.

Capital also has negative and significant impact on corporate governance state of the company. As the capital increases, the ratio of salary and other perquisites of directors will be in a declining position and vice versa. Capital may be enhanced by increasing the debt or by issuing shares and raising the capital. Debt increase will also enhance the fixed costs of the company and can lead to bankruptcy position in future. It also strikes investors to start demanding higher equity return in the market. Share issue has an initial costs but feasible to most of the investors. It is, therefore, difficult to explain that this negative relationship is due to debt or equity level in the capital.

Investment decisions show the strategic direction of a firm. Larger investment in liquid assets restricts the firm to get benefit from growth opportunities exist in the market. Moreover, liquid assets also include cash balance which may be used to undertake any project without going into the market, hence no more monitoring by outside investors are needed. The result reveals that firms heavily invest in current assets as compared to fixed assets. It may be deduced that directors use this money on their discretion.

\subsection{Reasons of Circularity Debt}

Since dependent variable in the proposition II is dichotomous, we applied logistic regression. Circularity debt is taken as a proxy of liquidity problem exists in public listed firms of Pakistan. It takes the value of 1 if any company faces this phenomenon and 0 otherwise. Table 9 presents the results of logistic regression.

As expected, the negative sign of the corporate governance shows the acceptance of our hypothesis that circularity debt exists because of bad corporate governance in the energy sector of Pakistan. As discussed that the figures of circularity debt are the accounting treatment of receivables and payables. Since table 3 shows positive difference, it is evidenced that this problem is not because of financial management but of corporate governance. Corporate governance (PREDCG) is the predicted values taken from model 1 which means that it is itself the function of some exogenous variables. In other words, variables which explain the phenomenon of corporate governance is badly managed which causes the increase in circularity debt.

It is Interesting to note that an increase in long term debt is linearly related to the problem of circularity debt. Debt is used to finance any new project which is supposed to generate positive net present value in order to maximize shareholders' wealth. If LTD is used for this purpose, then there is economic significance of this result. This result does not follow either pecking order or free cash flow theory. The evidence of trade-off theory with respect to 
leverage is unknown. Cash flow to noncash assets is also significantly positive which means circularity debt tends to increase with cash flows. This is consistent with the pecking order theory which implies that when cash flows are high, corporations use this cash to finance new projects, settle their liabilities, pay dividends and finally accumulate cash to manage working capital requirements. When we look at the result of capital expenditure to noncash assets (CAPEXTNAST), it is significantly negative, showing evidence that firms with high cash flows invest in fixed assets which cause to accumulate the amount of circularity debt. The remaining cash is kept a side for day to day activity. Results show that an increase in sales also helps circularity debt to pile up. Since all sales are made on credit, we assume this result is as per our expectations. These credit sales are not converted into cash in near future, the amount of circularity debt increases. In other words, this result is following the pecking order as well as free cash flow theory. We can conclude this result by combining all variables into consideration. Companies make credit sales and somehow generate operating cash flows to fulfill the working capital requirements. Since this cash is not enough to finance new profitable projects, due to increase in receivables, they have to take long term loans.

\subsection{Determinants of Corporate Savings}

Table 9 shows that both of the predictors positively and significantly explain the variation in corporate savings. Overall model is significant and explaining $56.10 \%$ variation. Liquidity is the predicted value taken from model 2 which is itself a function of some exogenous variables. The magnitude of ROE is greater than the magnitude of liquidity.

\subsection{Corporate Savings as predictor of Total Investment in a Country}

The study of economic variables requires deep understanding of their various roots in order to appropriately justify. Gross fixed capital formation (GFCF) as a proxy of total investment in a country has different linkages when relate with the corporate sector. Second problem is determining the suitable time lag between dependent and explanatory variables. This thesis has a basic premise that corporate savings are a good predictor of total investment in a country in form of GFCF. As a result of increasing retained earnings by corporations, the country may face a rapid growth in terms of investments. It is a strategic decision by firms to decide about retained earnings and requires the approval of Board of directors (BoD). The time lag between the approval of BoD and actual capital expenditure is a crucial problem. Lund and Holden (1968) discussed the total lag pertaining to a particular investment in fixed assets by a firm consist of a fixed and a distributed component and it becomes further complicated when looking at an aggregate level like industry or the whole economy. He proposed a capital stock adjustment model and found satisfactory to explain the private gross fixed capital formation in the UK during 1923 to 1938. Companies in various industries respond to a situation with different lags based on time-varying cash flows, risk involved in that particular capital expenditure, time lapses between capital expenditure today and benefits to be anticipated in future and the like. Firms in the same industry respond differently in term of dividend announcement and retained earnings. Since mechanism of every industry is different, it is hard to decide which tame lag is an appropriate one. The nature of both of the variables in the last proposition is time series which have different implications at each time lag. It is assumed that investment in fixed assets by corporations will be a part of total investment of a country in the next year. Corporate savings are assumed to have one lag to explain the variation in GFCF of Pakistan. 


\subsection{Rational behind the Notion}

The responsibility of social welfare has been partially shifted from government to private sector of the economy worldwide. A corporation is meant an institution which must fulfill, at least, the basic needs of common people. Although government is accountable to do the same, with the development of economy it is assumed that this job is done by corporate sector as well. Corporation is a nexus of different contracts with the society associated with it (Jensen and Meckling, 1976). It is not simply a firm to make profit but also an institution to have a responsibility of social wellbeing of common people. An investment decision by a corporation is taken as a strategic direction which may lead the firm to outperform in the market. As a result of this decision, several changes can be observed in the society which can be traced from several perspectives. This whole process can also be depicted by figure 4 below. The two side arrows show that both of the parties in the process will get benefit.

\subsection{Descriptive nature of the data}

We start the empirical part of by explaining the descriptive part of the data in table 10. At lag 1 , both of the variables have far reach mean scores. When taking second lag of retained earnings, the mean values of both of the variables come to nearest of each other. It shows that any investment by corporations will be part of the investment of the country after one and two years. Later results are much supportive as compared to earlier one.

\subsection{Exploring the role of Corporate Savings}

Today, energy sector of Pakistan needs more attention in terms of investments in electricity plants, water dams and new technologies to generate more electricity in the country. These investment decisions by corporations in this sector can also boost up total investment in the country in the form of GFCF. Corporations can only take these decisions when they have sufficient available cash. Therefore, it may be deduced here that corporate savings are an important strategic decisions to prosper the country. Table 11 shows this empirical result.

This is also tested by taking the second lag of retained earnings but results are still supportive of this notion. This is given in table 12. Second lag of retained earnings make the results more strong as the magnitude of the coefficient becomes more significant as compared to first lag. It shows that the results of second lag are more pronounced than the results of first lag.

\section{CONCLUSION}

The present research is a blend of economic governance and development financing. It develops a theorem, identifying antecedent variables which can better expound the given phenomenon. It has now come into the fact that investment position in a country can be improved if corporate sector plays its rigorous role to convert its earnings into investment. It was deduced from the theorem which states that the state of corporate governance must be improved in order to minimize the circularity debt problem which is really a governance issue. Resolution of this issue will lead the corporate sector to raise their liquidity and profitability as well. Government must focus on the issue of circularity debt from the governance point of view rather from the perspective of finance. Government is responsible to create a business environment where transparent management of public finance becomes possible at the national level. In case the government regulation is not efficient, rules of conduct for the private sector are desired. Particularly, improving the corporate social responsibility and relevance of corporate governance are needed. 


\section{REFERENCES:}

Altman, I E (1993). Corporate Financial Distress and Bankruptcy: A Complete Guide to Predicting and Avoiding Distress and Profiting from Bankruptcy, John Wiley and Sons, New York

Bhole L.M and Jitendra Mahakud (2005). Trends and Determinants of Private Corporate Sector Savings in India. Economic and Political Weekly, Vol.40, No.39, pp. 42434250

Chandra P. (2002). Financial Management, Theory and Practice, Tata McGraw-Hill Publishing Company, New Delhi

D'Souza Errol (2000). Structure of Corporate Finance and Corporate Governance in India. Economic and Political Weekly, Vol. 35, No.48, pp. 4196-4205

Dixit Avinash (2008). Economic Goverannce. Intertic Lecture, University of Mian Bicocca

Dobrovolsky Sergei P. (1945). Corporate Retained Earnings and Cyclical Fluctuations. The American Economic Review, Vol.35, No.4, pp. 559-574

García-Teruel Pedro J., Pedro Martinez-Solano and Juan (2009). Accruals Quality and Corporate Cash Holdings. Accounting \& Finance, Vol. 49, No.1, pp. 95-115

Jensen M. and W. Meckling (1976). Theory of the Firm: Managerial Behavior, Agency Costs and Ownership Structure. Journal of Financial Economics, Vol.3, No.4, pp.305-360

Judge, G.G., W.E. Griffiths, R.C. Hill, H. Luthepohl and T-C. Lee (1985). The Theory and Practice of Econometrics. Wiley, New York.

Lintner John (1956). Distribution of Incomes of Corporations Among Dividends, Retained Earnings and Taxes. The American Economic Review, Vol.46, No.2, pp. 97-113

Lund P.J. and K. Holden (1968). An Econometric Study of Private Sector Gross Fixed Capital Formation in the United Kingdom, 1923-1938. Oxford Economic papers, New Series, Vol.20, No.1, pp. 56-73

Myers S. and N. Majluf (1984). Financing Decisions When Firms Have Investment Information That Investors Do Not. Journal of Financial Economics, Vol.13, No.2, pp. $187-220$

Planning Commission of Pakistan (2013). The Causes and Impacts of Power Sector Circular Debt in Pakistan. Commissioned by Planning Commission of Pakistan, Funded by USAID

Singh and J. Hamid (1992). Corporate Financial Structures in Developing Countries. IFC Technical Paper, No. 1, (Washington: International Finance Corporations)

Shanta (1982). Trends in Private Corporate Savings. Economic and Political Weekly, Vol. 17, No.45, pp. 1818-1827

Turnovsky (1967). The Allocation of Corporate Profits between Dividends and Retained Earnings. The Review of Economics and Statistics, Vol. 49, No. 4, pp. 583-589

Vitols Sigurt (1995). Corporate Governance Versus Economic Governance: Banks and Industrial Restructuring in the U.A. and Germany. Discussion Paper

Weidenhammer (1933). Causes and Repercussions of the Faulty Investment of Corporate Savings. The American Economic Review, Vol. 23, No. 1, pp. 35-41

Williamson, O. (2005). The economics of governance. American Economic Review, Vol.95, No.2, pp. 1-18

Zheka Vitaliy (2007). The Impact of Corporate Governance Practices on Dynamic Adjustment of Capital Structure of Companies in Ukraine. EERC Working Paper Series. 


\section{APPENDIX}

Table 1: Receivables from DISCOs (Million Rs.)

\begin{tabular}{|c|c|c|c|c|c|}
\hline DISCOs & $\mathbf{2 0 0 8 - 0 9}$ & $\mathbf{2 0 0 9 - 1 0}$ & $\mathbf{2 0 1 0 - 1 1}$ & $\mathbf{2 0 1 1 - 1 2}$ & \% Share \\
\hline PESCO $^{*}$ & 26,809 & 32,902 & 41,282 & 51,360 & $26 \%$ \\
\hline HESCO & 18,856 & 25,454 & 33,344 & 44,237 & $22 \%$ \\
\hline QESCO & 4,297 & 5,238 & 24,780 & 48,193 & $24 \%$ \\
\hline LESCO & 10,957 & 15,968 & 17,081 & 23,080 & $12 \%$ \\
\hline GEPCO & 3,585 & 5,322 & 5,631 & 5,912 & $3 \%$ \\
\hline FESCO & 3,719 & 5,676 & 5,866 & 7,068 & $4 \%$ \\
\hline IESCO & 2,287 & 2,286 & 2,762 & 2,703 & $1 \%$ \\
\hline MEPCO & 7,252 & 10,505 & 11,900 & 14,638 & $7 \%$ \\
\hline Total & $\mathbf{7 7 , 7 6 2}$ & $\mathbf{1 0 3 , 3 5 1}$ & $\mathbf{1 4 2 , 6 4 6}$ & $\mathbf{1 9 7 , 1 9 1}$ & $\mathbf{1 0 0 \%}$ \\
\hline
\end{tabular}

Source: Monthly Economic Review Saturday, $29^{\text {th }}$ November 2014

*PESCO includes TESCO and HESCO includes SEPC

Table 2: Receivables of DISCOs from Provinces and AJK (Million Rs.)

\begin{tabular}{|l|l|l|l|l|l|l|l|l|}
\hline Province & $\mathbf{2 0 0 5}$ & $\mathbf{2 0 0 6}$ & $\mathbf{2 0 0 7}$ & $\mathbf{2 0 0 8}$ & $\mathbf{2 0 0 9}$ & $\mathbf{2 0 1 0}$ & $\mathbf{2 0 1 1}$ & $\mathbf{2 0 1 2}$ \\
\hline Punjab & $(481)$ & $(9)$ & $(381)$ & 162 & $(7)$ & 3,263 & 5,371 & 5,842 \\
\hline KPK & 239 & 398 & 652 & 254 & 601 & 1,144 & 19,427 & 19,792 \\
\hline Balochistan & 538 & 119 & 146 & 709 & 1,064 & 2,419 & 4,662 & 52,696 \\
\hline Sindh & 341 & 2,382 & 3,224 & 7,603 & 14,241 & 25,790 & 39,230 & 6,200 \\
\hline AJ\&K & $(50)$ & 485 & 756 & 1,216 & 2,391 & 4,393 & 9,888 & 15,953 \\
\hline Total & $\mathbf{5 8 7}$ & $\mathbf{3 , 3 7 5}$ & $\mathbf{4 , 3 9 7}$ & $\mathbf{9 , 9 4 4}$ & $\mathbf{1 8 , 2 9 0}$ & $\mathbf{3 7 , 0 0 9}$ & $\mathbf{7 8 , 5 7 8}$ & $\mathbf{1 0 0 , 4 8 3}$ \\
\hline
\end{tabular}
2012)

Primary Source: PEPCO DISCOs Performance Statistics Report (FY 2005 - FY

Secondary Source: USAID Report; The Causes and Impact of Circular Debt exist in Power Sector in Pakistan 2013

\begin{tabular}{|l|c|c|c|c|c|}
\hline \multicolumn{5}{|c|}{ Table 3: Distribution of Circularity Debt Receivables (Billion Rs.) } \\
\cline { 4 - 6 } Company & Receivables & Payables & Net Position & \multirow{2}{*}{ Change } \\
\cline { 3 - 6 } & & & 30-Apr-11 & 30-Apr-10 & \\
\hline PSO & 149 & 98 & 51 & 30 & 21 \\
\hline SSGCL & 51 & 44 & 7 & -1 & 8 \\
\hline SNGPL & 11 & 25 & -13 & -9 & -5 \\
\hline PEPCO & 304 & 302 & 3 & -40 & 42 \\
\hline OGDCL & 116 & 0 & 116 & 80 & 36 \\
\hline PARCO & 38 & - & 38 & 30 & 8 \\
\hline KESC & 68 & 40 & 28 & -24 & 51 \\
\hline GHPL & 10 & - & 10 & 11 & -1 \\
\hline PPL & 22 & - & 22 & 26 & -4 \\
\hline KW\&SB & 7 & 8 & -1 & 0 & -1 \\
\hline Grand Total & $\mathbf{7 7 5}$ & $\mathbf{5 1 7}$ & $\mathbf{2 5 9}$ & $\mathbf{1 0 4}$ & $\mathbf{1 5 5}$ \\
\hline Source: Ministry of Finance & \multicolumn{5}{|l}{} \\
\hline
\end{tabular}




\begin{tabular}{|l|l|l|l|l|l|}
\hline \multicolumn{5}{|c|}{ Table 4: Financing of Top 50 Listed Manufacturing Companies } \\
\hline Period & Country & $\begin{array}{l}\text { Internal } \\
\text { Finance Long } \\
\text { Term }\end{array}$ & $\begin{array}{l}\text { External } \\
\text { Finance } \\
\text { Equity }\end{array}$ & $\begin{array}{l}\text { Average } \\
\text { External } \\
\text { Finance } \\
\text { Long Term } \\
\text { Debt }\end{array}$ & $\begin{array}{l}\text { Change in } \\
\text { Internal } \\
\text { Finance }\end{array}$ \\
\hline $1980-87$ & Korea & 12.8 & 40.3 & 45.4 & 7.6 \\
\hline $1980-86$ & Pakistan & 58.3 & 12.3 & 16.1 & -4.6 \\
\hline $1980-87$ & Jordan & 5.8 & 84.1 & 16.4 & -24.1 \\
\hline $1983-87$ & Thailand & 17.3 & Na & Na & 23.1 \\
\hline $1984-88$ & Mexico & 17.1 & 76.0 & 2.9 & 14.9 \\
\hline $1980-88$ & India & 36.1 & 11.0 & 45.6 & -12.6 \\
\hline $1982-87$ & Turkey & 18.1 & 60.5 & 15.5 & 13.2 \\
\hline $1983-87$ & Malaysia & 42.4 & 31.4 & 2.1 & -7.7 \\
\hline $1980-88$ & Zimbabwe & 58.5 & 43.0 & 0.0 & 16.8 \\
\hline
\end{tabular}

Source: Singh and Hamid (1992), Table III. 10, p 43.

\begin{tabular}{|c|c|c|}
\hline \multicolumn{3}{|c|}{ Table 5: Investment as a percentage of GDP } \\
\hline Year & FDI as of GDP & $\begin{array}{c}\text { Domestic Investment } \\
\text { (GFCF) }\end{array}$ \\
\hline 1990-91 & 0.61 & 17.30 \\
\hline 1991-92 & 0.57 & 17.47 \\
\hline 1992-93 & 0.69 & 18.69 \\
\hline 1993-94 & 0.68 & 19.24 \\
\hline 1994-95 & 0.81 & 17.97 \\
\hline $1995-96$ & 1.19 & 17.03 \\
\hline 1996-97 & 1.46 & 17.38 \\
\hline 1997-98 & 1.15 & 16.34 \\
\hline 1998-99 & 0.81 & 15.04 \\
\hline $1999-00$ & 0.84 & 13.93 \\
\hline $2000-01$ & 0.42 & 16.01 \\
\hline 2001-02 & 0.54 & 15.84 \\
\hline $2002-03$ & 1.15 & 15.46 \\
\hline $2003-04$ & 0.65 & 15.27 \\
\hline $2004-05$ & 1.16 & 15.63 \\
\hline 2005-06 & 1.97 & 15.26 \\
\hline 2006-07 & 1.43 & 15.40 \\
\hline 2007-08 & 1.03 & 15.55 \\
\hline
\end{tabular}

Source: World Bank (2007) 


\begin{tabular}{|lll|}
\hline \multicolumn{2}{|c|}{ Table 6: List of Abbreviations of Variables } \\
\hline S.NO. & Variable & Description \\
\hline 1 & CG & Corporate Governance \\
\hline 2 & ORGTYP & Type of the Organization \\
\hline 3 & OWNCONCT & Ownership Concentration \\
\hline 4 & LOGCAP & log of Capital \\
\hline 5 & CAFA & Current Assets divided by Fixed Assets \\
\hline 6 & CD & Circularity Debt \\
\hline 7 & LOGLTD & Log of Long Term Debt \\
\hline 8 & CFTNAST & Cash Flow to Net Assets \\
\hline 9 & CAPEXPTNAST & Capital Expenditure to Net Assets \\
\hline 10 & LOGSALES & Log of Sales \\
\hline 11 & LOGRE & Log of Retained Earnings \\
\hline 12 & ROE & Return on Equity \\
\hline 13 & GFCF & Gross Fixed Capital Formation as Macro \\
Level Investment in a Country & \\
\hline
\end{tabular}

\begin{tabular}{|c|c|c|c|}
\hline \multicolumn{4}{|c|}{ Table 7: Variables } \\
\hline $\begin{array}{l}\text { Dependent } \\
\text { Variable }\end{array}$ & Determinants & $\begin{array}{l}\text { Independent } \\
\text { Variables }\end{array}$ & Determinants \\
\hline $\begin{array}{l}\text { Corporate } \\
\text { Governance }\end{array}$ & $\begin{array}{l}\text { A Ratio of Salary \& } \\
\text { Other Perquisites of } \\
\text { Management to Capital }\end{array}$ & $\begin{array}{l}>\quad \text { Type of the } \\
\text { organization } \\
>\quad \text { Ownership } \\
\text { Concentration } \\
>\quad \text { Capital } \\
>\quad \text { Distribution of } \\
\text { Assets }\end{array}$ & $\begin{array}{l}\text { Government or Non- } \\
\text { government } \\
\text { held by directors } \\
\text { Assets } \\
\text { LTD+Equity } \\
\text { Current Asset / Fixed }\end{array}$ \\
\hline Liquidity & $\begin{array}{l}>\quad \text { Circularity Debt } \\
1=\text { circularity debt exist } 0= \\
\text { otherwise }\end{array}$ & $\begin{array}{l}\text { Corporate } \\
\text { Governance } \\
>\quad \text { LTD } \\
\text { Cash Generated } \\
\text { during the year } \\
>\quad \text { Corporate Assets } \\
>\quad \text { Sales }\end{array}$ & $\begin{array}{l}>\quad \text { From Model } 1 \\
\\
\\
\text { Noncash Assets } \\
\text { Long Term Debt } \\
\text { Noncash Assets } \\
>\quad \text { Log of Sales }\end{array}$ \\
\hline Retention & Retained Earnings & $\begin{array}{ll}> & \text { Liquidity } \\
> & \text { Earnings }\end{array}$ & $\begin{array}{ll}> & \text { From Model } 2 \\
& \text { ROE }\end{array}$ \\
\hline $\begin{array}{l}\text { Macro Level } \\
\text { Investment in the } \\
\text { Country }\end{array}$ & $\begin{array}{l}>\quad \text { Gross Fixed Capital } \\
\text { Formation }\end{array}$ & Corporate Savings & Retained Earnings \\
\hline
\end{tabular}




\begin{tabular}{|l|l|l|l|}
\hline \multicolumn{4}{|c|}{ Table 8: Descriptive Analysis } \\
\cline { 1 - 3 } Variables & $\underline{\text { Mean }}$ & $\underline{\text { Standard Deviation }}$ & No. of observations \\
\hline LOGCG & -0.052466 & 0.5636108 & 167 \\
\hline TORG & 0.41 & 0.493 & 167 \\
\hline OWNCON & 7.42338 & 16.4881571 & 167 \\
\hline LOGCAP & 7.0515 & 0.68123 & 167 \\
\hline PREDCG & -0.0903 & 0.343 & 177 \\
\hline LOGLTD & 6.004 & 1.451 & 180 \\
\hline LOGSALES & 7.350 & 0.961 & 182 \\
\hline LOGRE & 5.9146 & 0.915 & 114 \\
\hline PREDLIQ & 0.266181 & 0.336 & 114 \\
\hline ROE & 34.1135 & 26.512 & 114 \\
\hline
\end{tabular}

\begin{tabular}{|c|c|c|c|c|c|c|c|c|}
\hline \multicolumn{9}{|c|}{ Table 9: Results } \\
\hline \multicolumn{3}{|c|}{ Proposition 1} & \multicolumn{3}{|c|}{ Proposition 2} & \multicolumn{3}{|c|}{ Proposition 3} \\
\hline Variables & Coefficient & $\begin{array}{c}\text { Std. } \\
\text { Error }\end{array}$ & Variables & Coefficient & $\begin{array}{c}\text { Std. } \\
\text { Error }\end{array}$ & Variables & Coefficient & Std. Error \\
\hline Intercept & -0.462 & 0.584 & Intercept & -45.893 & 8.291 & Intercept & $\begin{array}{c}4.964 \\
(50.865\end{array}$ & 0.098 \\
\hline TORG & $\begin{array}{l}0.175^{*} \\
(1.941)\end{array}$ & 0.090 & PREDCG & $-2.547^{*}$ & 1.294 & PREDLIQ & $\begin{array}{l}1.051^{*} \\
(6.044)\end{array}$ & 0.174 \\
\hline $\begin{array}{l}\text { OWNCO } \\
\mathrm{N}\end{array}$ & $\begin{array}{l}-0.012^{*} \\
(-4.744)\end{array}$ & 0.003 & LOGLTD & $1.845^{*}$ & 0.464 & ROE & $\begin{array}{l}0.020^{*} \\
(8.924)\end{array}$ & 0.002 \\
\hline LOGCAP & $\begin{array}{l}-0.148^{*} \\
(-2.200)\end{array}$ & 0.067 & $\begin{array}{l}\text { CFTNAS } \\
\mathrm{T}\end{array}$ & $0.041^{*}$ & 0.016 & No. of Obs. & 113 & \\
\hline \multirow[t]{2}{*}{ CA/FA } & $\begin{array}{l}0.015^{*} \\
(4.868)\end{array}$ & 0.003 & $\begin{array}{l}\text { CAPEXT } \\
\text { NAST }\end{array}$ & $-0.014^{*}$ & 0.008 & & & \\
\hline & & & $\begin{array}{l}\text { LOGSAL } \\
\text { ES }\end{array}$ & $4.201^{*}$ & 0.952 & & & \\
\hline $\begin{array}{l}\text { Adjusted } \\
\mathbf{R}^{2}\end{array}$ & 0.276 & & & & & ${\text { Adjusted } R^{2}}^{2}$ & 0.561 & \\
\hline $\begin{array}{l}\text { F } \\
\text { Statistics }\end{array}$ & 16.837 & & & & & F Statistics & 73.124 & \\
\hline
\end{tabular}

* Significant at the 5 percent levels

$\mathrm{t}$ statistics are in parenthesis

\begin{tabular}{|l|c|c|c|c|c|}
\hline \multicolumn{7}{|c|}{ Table 10: Descriptive Analysis } \\
\hline \multicolumn{3}{|c|}{ Lag 1 } & \multicolumn{3}{c|}{ Lag 2 } \\
\hline Variables & Mean & Std.Dev. & Variables & Mean & Std.Dev. \\
\hline GFCF & 5.65700 & 6.8923300 & GFCF & 5.81200 & 6.9289000 \\
\hline RE $_{\mathrm{t}-1}$ & 1.00300 & 2.4724500 & RE $_{\mathrm{t}-2}$ & 7.607600 & 2.0276500 \\
\hline
\end{tabular}


Table 11: Predicting the GFCF

\begin{tabular}{|l|c|c|}
\hline \multirow{2}{*}{ Variables } & \multicolumn{2}{|c|}{ Model } \\
\cline { 2 - 3 } & $\begin{array}{c}\text { Coefficie } \\
\text { nt }\end{array}$ & $\begin{array}{c}\text { Std. } \\
\text { Error }\end{array}$ \\
\hline Intercept & $\begin{array}{c}3.89100 \\
(3.981)\end{array}$ & 9.77300 \\
\hline $\mathrm{RE}_{\mathrm{t}-1}$ & 17.601 & 3.707 \\
& $(4.748)$ & \\
\hline $\mathrm{R}^{2}$ & 0.399 & \\
\hline F Statistics & 22.541 & \\
\hline
\end{tabular}

* Significant at the 5 percent levels $\mathrm{t}$ statistics are in parenthesis .

Table 12: Predicting the GFCF

\begin{tabular}{|l|c|c|}
\hline \multirow{2}{*}{ Variables } & \multicolumn{2}{|c|}{ Model } \\
\cline { 2 - 3 } & $\begin{array}{c}\text { Coefficie } \\
\text { nt }\end{array}$ & $\begin{array}{c}\text { Std. } \\
\text { Error }\end{array}$ \\
\hline Intercept & $\begin{array}{c}4.21900 \\
(14.197)\end{array}$ & 1.00500 \\
\hline $\mathrm{RE}_{\mathrm{t}-2}$ & 20.942 & 4.701 \\
& $(4.455)$ & \\
\hline $\mathrm{R}^{2}$ & 0.357 & \\
\hline F Statistics & 19.849 & \\
\hline
\end{tabular}

* Significant at the 5 percent levels

$\mathrm{t}$ statistics are in parenthesis . 


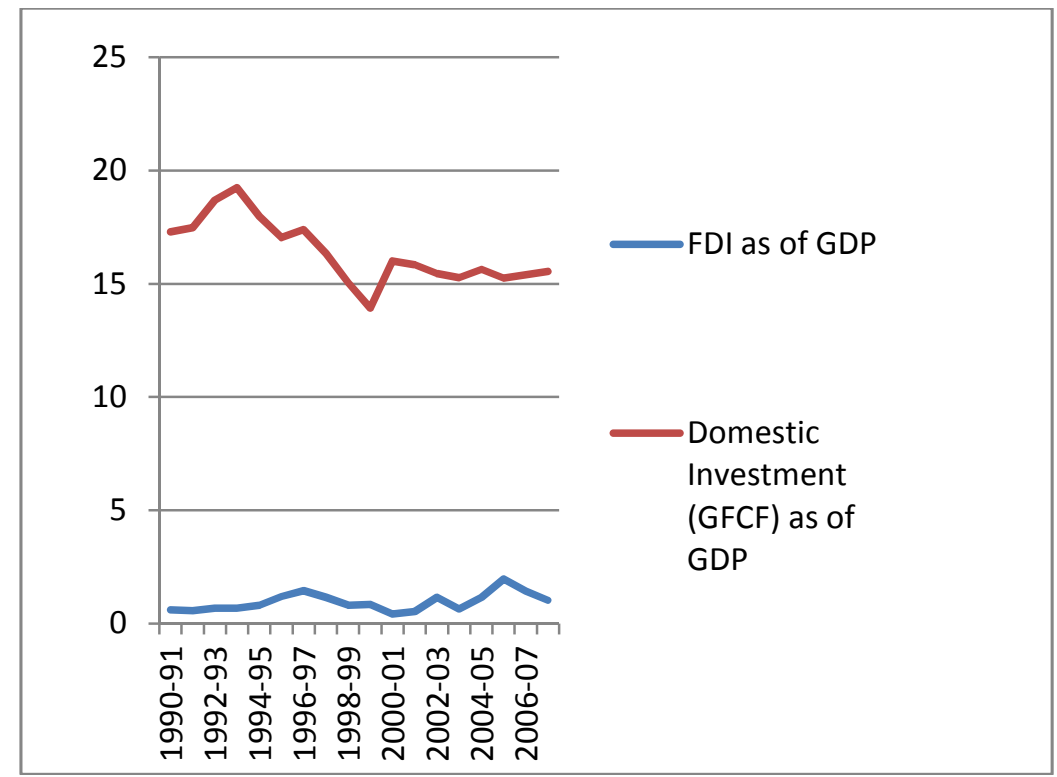

Figure 1 Investment as Percentage of GDP

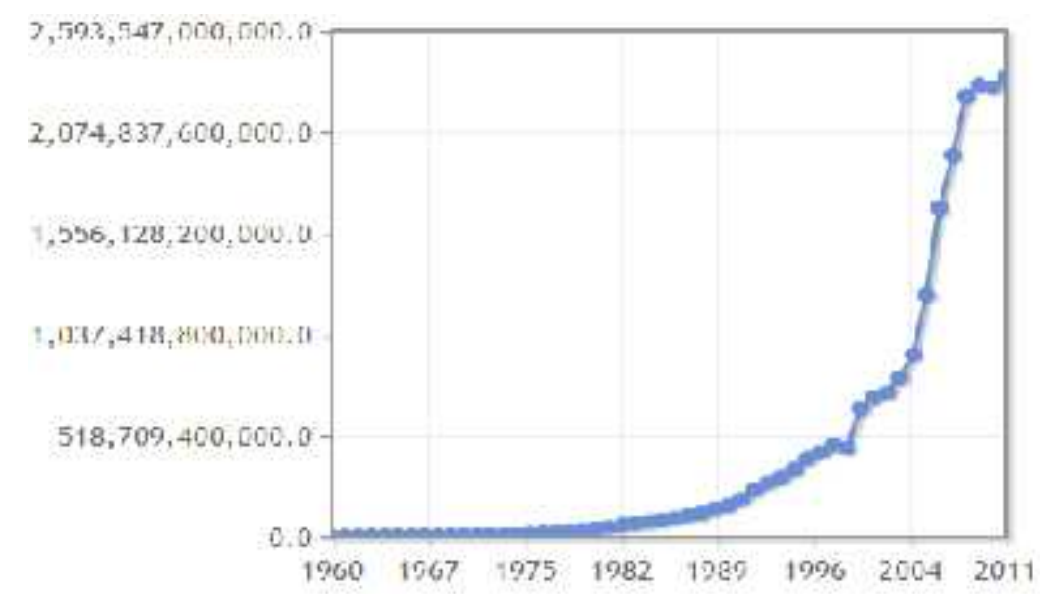

Figure 2 Gross Fixed Capital Formation History in Pakistan 


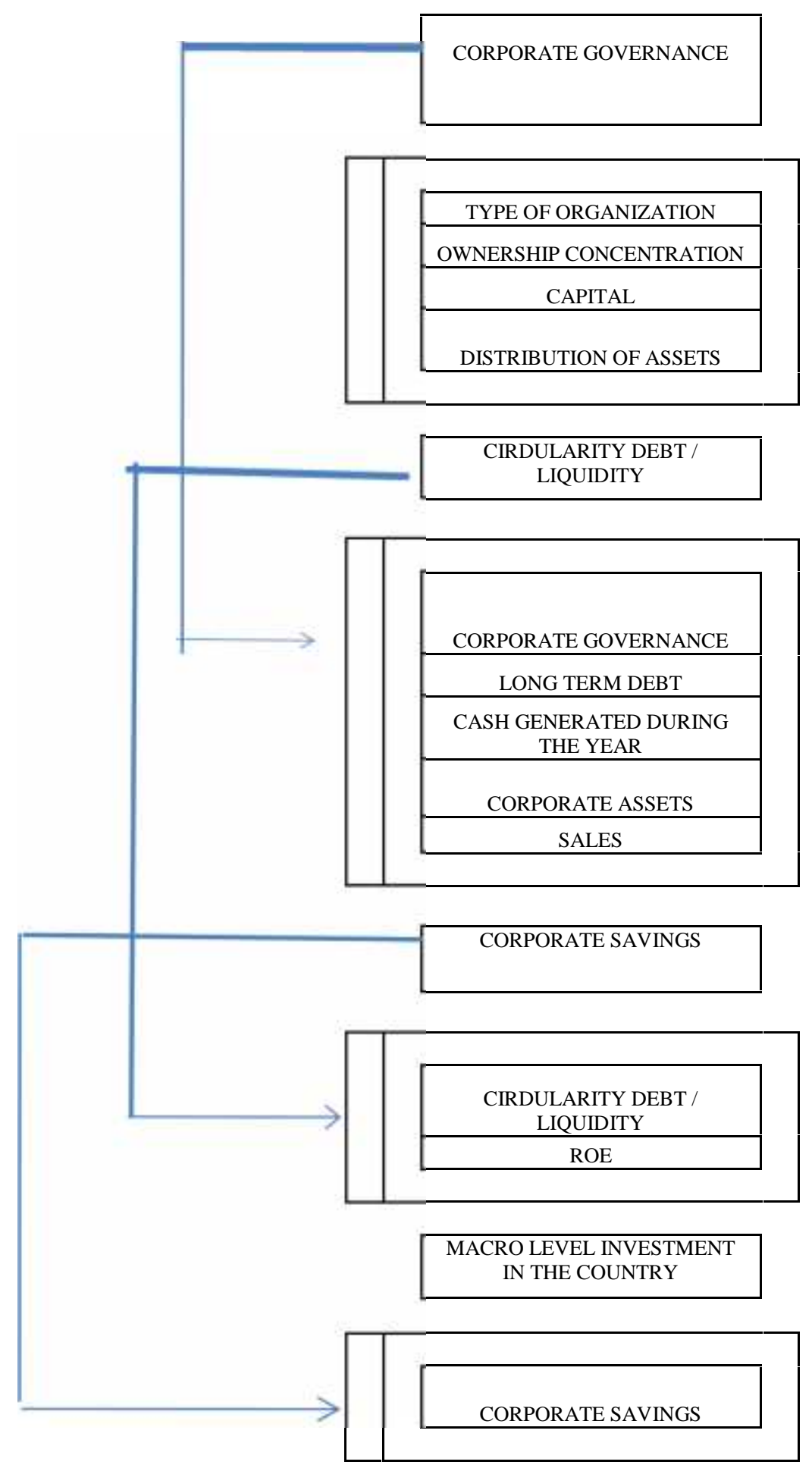

Figure 3 An Econometric Model of Corporate Governance and Circularity Debt 


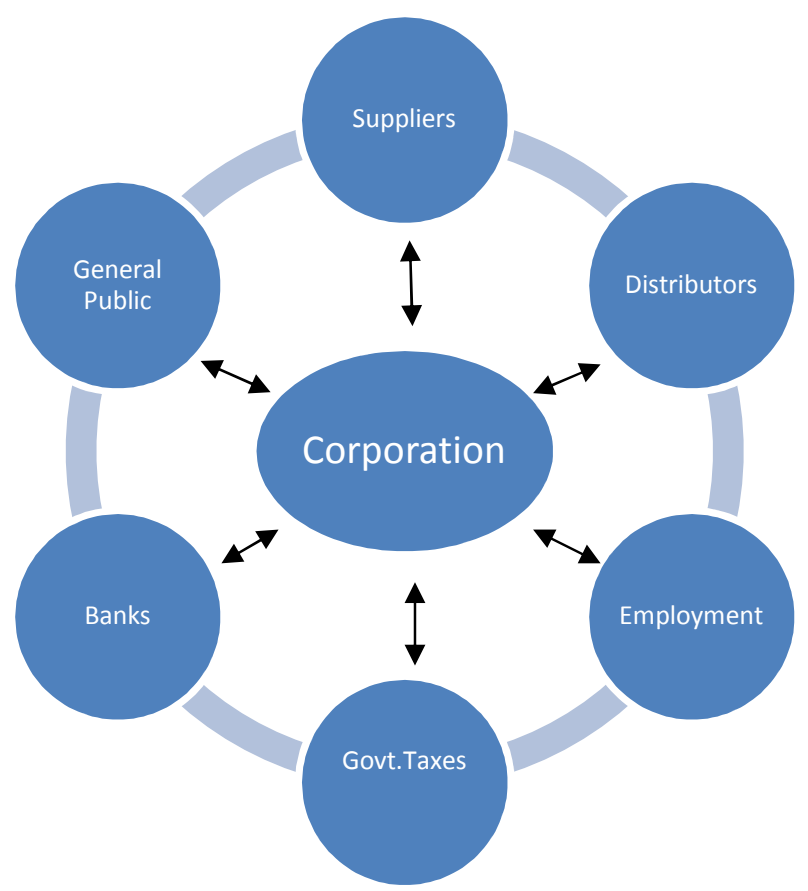

Figure 4 Corporation as a Nexus of Contracts 